Vol. 2 No. 1- April 2021

\title{
Indonesian Voting from Abroad: Highly Educated Citizen Participation in the 2019 Election at Tokyo Polling Station
}

\author{
Sri Endah Pujiatin \\ Master of Economic Planning and Development Policy, Faculty of Economics \\ and Business University of Indonesia, Depok, Indonesia \\ sriendah_puji@yahoo.com
}

\begin{abstract}
The political rights of Indonesian citizens living abroad have been guaranteed by law since 1953 and implemented by a joint committee between the General Election Commission and the Ministry of Foreign Affairs. As a developing country with increasing democracy, Indonesia's external voting needs to be studied. Using the qualitative analysis of macro data and questionnaire survey in Tokyo, this study addresses the following questions: How is the implementation of external voting by the Indonesian government? How is the voter? How does the registration, administration, voting facilitation, and voting method influence voter participation in home country elections? The findings suggest that the government provides many resources to facilitate external voting. Nevertheless, survey results revealed that some facilitation was inadequate compare to the number of voters. Although highly educated citizens tend to have a high awareness of home country elections, problems in voting facilitation might prevent them from voting.
\end{abstract}

Keywords: external voting, participation in politic, institutional factors.

ARTICLE INFO
Received: February 03, 2021
Received in revised form: March 22, 2021
Accepted: April 16, 2021

JISDeP - The Journal of Indonesia Sustainable Development Planning Published by Centre for Planners' Development, Education, and Training (Pusbindiklatren), Ministry of National Development Planning/ National Development Planning Agency (Bappenas), Republic of Indonesia
Address: Jalan Proklamasi 70,

Central Jakarta, Indonesia 10320

Phone: +62 $2131928280 / 31928285$

Fax: +62 2131928281

E-mail:

journal.pusbindiklatren@bappenas.go.id

Supported by Indonesian Development Planners Association (PPPI) 


\section{Introduction}

Many countries believe that citizens living abroad, similar to the citizens in their home country, should have the right to vote in their home country's elections. These non-residence citizens continue to grow. Department of Economic and Social Affairs of the United Nations (Department of Economic and Social Affairs United Nations, 2020) revealed that international migrants reached 272 million in 2019, and it is very important to guarantee their right to vote in elections. Several developed and developing countries have granted and facilitated the political rights of these expatriates. Despite differences in the regulation and implementation, a total of 115 countries have implemented external voting in their democratic practices, including Indonesia (Ellis et al., 2007). Indonesia, which started acknowledging external voting in 1953 (law number 7 of 1953), is one of the few countries that had adopted voting from outside the territory early on along with several developed countries such as the United Kingdom (1918), Norway (1921), United States (1942), Canada (1945), Australia (1949), Germany (1949), Iceland (1949), Finland (1958), and Sweden (1968) and is the first among developing countries (Sevi et al., 2020).

Granting the right to participate in politics for citizens living outside the territory of a country is part of the realization of goal 16 of the SDGs' 17 goals: strengthening an inclusive and peaceful society for sustainable development, providing access to justice for all, and building effective, accountable and inclusive institutions at all levels. Citizens who live outside the country's territory are a group of the population who must be given the same rights as citizens inside the territory in decision-making.

Indonesia has extensive experience in external voting implementation through overseas polling stations. In total, the Indonesian government conducted 16 external voting sessions (presidential and parliamentary elections) since 1971. Numerous polling stations were built at all embassies and consulates abroad to facilitate the voting. Based on the National Election Commission (KPU) report, 130 overseas polling stations were provided to facilitate more than 2 million overseas voters in the 2019 parliamentary and presidential elections. This exercise required considerable human resources and budgets, i.e., 556 personnel of the Overseas Election Committee (PPLN), 12,765 personnel of Overseas Voting Organizer Groups (KPPSLN), and 1,200 personnel of Voter Data Updating Committee (Pantarlih) (Kelompok Kerja Pembina Pemilihan Umum Luar Negeri, 2019). In addition, around 621 billion rupiahs were allocated to all overseas polling stations (Kelompok Kerja Pembina Pemilihan Umum Luar Negeri, 2019, pp. 171-174). The implementation of voting abroad has undergone several policy changes to increase public participation abroad in elections. Nevertheless, the level of citizen participation in the 2019 presidential elections was only $42.54 \%$.

There is a growing interest in external voting studies, but many of these studies focused on developed countries with long-established democracy, such as the United States, New Zealand, and Canada (Blais et al., 2019; Hanmer et al., 2015; Murray, 2012; Smith, 2010). However, research on the implementation of out-of-country voting in developing countries is still limited. No study specifically addresses the practice of polling stations abroad. Therefore, this study attempts to fill in the gap by exploring the implementation of external voting in Indonesia as a developing country with its long history of external voting implementation through overseas polling stations.

On the other hand, studies that focus on overseas citizen participation in home country elections are limited. Some studies describe several factors that influence overseas citizen participation in elections, for instance, institutional factors, type of election and voting method (Belchior et al., 2018), registration (Lafleur \& Chelius, 2011), political factors, level of democracy (Belchior et al., 2018; Ciornei \& ØstergaardNielsen, 2020), political rights and civil liberty scores (Sevi et al., 2020), socioeconomic factors, GDP (Belchior et al., 2018; Sevi et al., 2020), neighborhood characteristics (Herrnson et al., 2015; Murray, 2012), and demographic factors such as age (Sevi et al., 2020).

Given the importance of the institutional factor and overseas citizen participation in elections, this study aims to explore the Indonesian government's facilitation of external voting and its issues from the perspective of overseas voters with a focus on the Tokyo overseas polling station. This issue will be explored by answering the following questions: How is the implementation of external voting by the Indonesian government? How is the voter? How do the registration, administration, voting facilitation, and voting method influence voter participation in home country elections? For this purpose, the qualitative analysis of macro data and questionnaire surveys in Tokyo was used. 


\section{Literature Review}

\section{a. Vote from Outside of Territory}

Extraterritorial voting becomes increasingly important as the growing number of migrant citizens and many countries start to acknowledge their political rights. Extraterritorial voting, which also called external voting, or out-of-country voting, is defined as "provisions and procedures which enable some or all electors of a country who are temporarily or permanently outside the country to exercise their voting rights from outside the territory of the country" (Ellis et al., 2007, p. 67). More than half the countries in the world have acknowledged their citizens voting from abroad. Collyer (2014), for instance, revealed that up till 2009, 129 countries had implemented external voting.

However, the application of external voting in each country is not necessarily the same; there are many variations. Among the 129 countries that have implemented it, 13 countries provide direct representation for expatriate citizens, 93 countries accommodate the voting at the host country, and 23 countries require their expatriate voters to return to their home countries to vote (Collyer, 2014). Other differences also lie in the type of election allowed for external voters, expatriate citizen requirements for voting rights, and the voting method used (Ellis et al., 2007).

Despite the increasing number of countries using this measure, voting from abroad is complex and poses many challenges. A common challenge faced is the difficulty in determining the actual number of citizens living abroad. Studies in some countries have found that the number of registered voters in each country does not reflect the actual eligible voters abroad (Alarcon Jr, 2012; Burgess \& Tyburski, 2020; Ciornei \& Østergaard-Nielsen, 2020; Hafizy, 2017; Smith, 2010). To address this challenge, some studies utilize various sources to compare the numbers of overseas citizens. One alternative source that is commonly used to better estimate the number of overseas citizens is the Migrant Stock data published by the United Nations (Burgess \& Tyburski, 2020; Ciornei \& $\emptyset$ stergaard-Nielsen, 2020). The UN Migrant Stock provides the number of migrants by country of origin and destination, age, and gender, based on official data about foreign-born or foreign populations published by each country (Department of Economic and Social Affairs United Nations, 2020).

Furthermore, Ellis et al. (Ellis et al., 2007) revealed that differences in the social and cultural conditions of the host country compared to domestic and staff involved in external voting, who are mostly temporary, pose many challenges in voting work. Ellis et al. (Ellis et al., 2007) also added that external voting is difficult to implement because of the number of voters, their residences, and the voting system. Similarly, Hafizy (Hafizy, 2017) also revealed that different environmental settings in external voting cause election administrators and overseas voters to experience a higher level of difficulty than in the country of origin.

\section{b. Voter Participation and Influencing Factors}

There is a limited study that focuses on the participation of expatriate voters in domestic elections. A few studies have formulated certain demographic, institutional, socioeconomic, and political factors that influence expatriate voters' participation in their home country's politics (Belchior et al., 2018; Ciornei \& Østergaard-Nielsen, 2020; Lafleur \& Chelius, 2011; Sevi et al., 2020).

Institutional factors are believed to have a significant influence on increasing voter participation. One example is voting facilitation. Voting facilitation, such as the availability of voting via post, proxy, or internet (Belchior et al., 2018), considerably encourages the voters to participate because it saves their time and money, especially for those who live far from the polling station. Other important voting facilitations are the number and location of polling booths, access to information about voting, and logistical settings for voter registration (Bauböck, 2007). Despite their importance, due to their inaccessibility, Belchior et al. (2018) does not include these variables in his analysis.

Other studies have found other institutional factors, such as registration restrictions affecting voter participation. For instance, Lafleur \& Chelius (2011) states that stricter regulations on voter registration significantly influenced the level of external voter participation in the 2016 Mexican presidential election. He also discusses other demographic and socioeconomic variables as contributing factors for the low overseas participation in the Mexican election. Correspondingly, Hafizy (Hafizy, 2017) mentions that strict regulations on registration prevent many Indonesian expatriates from exercising their voting rights. To overcome this problem, the Indonesian government has relaxed restrictions on registration, resulting in a relatively high number, 335,679, of newly registered voters (Kelompok Kerja Pembina Pemilihan Umum Luar Negeri, 2019). 
On the other hand, a growing body of research on external voting mostly focuses on developed countries with long-established democracy, such as (Cain et al., 2008; Hanmer et al., 2015; Herrnson et al., 2015; Murray, 2012; Smith, 2010), Italy (Battiston \& Mascitelli, 2008), and Portugal (Belchior et al., 2018). The United States has advanced the voting method by using electronic media such as fax, email, or the internet (Cain et al., 2008; Hanmer et al., 2015). On the other hand, Italy (Battiston \& Mascitelli, 2008) and Portugal (Belchior et al., 2018) provide political representation for their expatriates. However, both of these aspects rarely exist in developing democracies.

Furthermore, studies on the implementation of out-of-country voting in developing countries are still limited. Among them are Alarcon Jr (Alarcon Jr, 2012) and (Kaario, 2018) who explored overseas voting in the Philippines, Low (Low, 2018), who explored overseas voting in Malaysia; and Şahin-Mencütek \& Erdoğan (Şahin-Mencütek \& Erdoğan, 2016) and Sevi et al. (Sevi et al., 2020), who studied Turkey's external voting. Unlike Indonesia, these countries do not have long experience in implementing voting from abroad. They began adopting voting from abroad in the 2000s, long after Indonesia began implementing it in 1971 (Pamungkas et al., 2019). Malaysia (Low, 2018) implemented external voting in 2003, the Philippines in 2004, Turkey in 2014, and Lebanon in 2018 (Sevi et al., 2020).

\section{c. The Case of Indonesia}

The complexity and challenges can be seen in the administration of the 2019 external voting by the Indonesian government. Indonesia, which has had the provision of external voting since 1953 (Ellis et al., 2007), started the implementation in its second election in 1971 (Pamungkas et al., 2019). As a country with long experience in the implementation of external voting, Indonesia and its government facilitates more than 2 million overseas voters with hundreds of external poll stations, thousands of human resources, and billions of rupiahs to administer the voting at 130 diplomatic stations in 96 countries (Kelompok Kerja Pembina Pemilihan Umum Luar Negeri, 2019). The 130 polling stations are supported by 556 Overseas Election Committee (PPLN), 1,200 Voter Data Updating Committee (Pantarlih), and 12,765 Overseas Voting Organizing Group (KPPSLN) employed for the 2019 election (Kelompok Kerja Pembina Pemilihan Umum Luar Negeri, 2019). They come from various backgrounds of the Indonesian diaspora and, as Ellis et al. (Ellis et al., 2007) mentioned, were temporarily employed.

To increase the participation of overseas citizens in elections, the government also provides numerous facilities for the three voting methods implemented. As many as 783 polling stations were prepared for direct voters, 2,345 ballot boxes for remoted voters, and 429 postal voting units for absentee voters (Kelompok Kerja Pembina Pemilihan Umum Luar Negeri, 2019). It is interesting that Indonesia specifically uses the mobile ballot box voting method in which the voting organizer comes to a group of emigrants who live in remote areas, cannot go to polling stations, or do not have access to postal services.

In addition, the government has established more flexible regulations on voter registration. The regulation accommodates traveling voters who have been registered as voters at one polling station, but they move/travel to another country to re-register themselves to vote at the nearest polling station at the new host country. These include the list of additional permanent voters (DPTb), and expatriate citizens who have not been registered as voters during the registration period who is included in the list of specific voters (DPK). Data from Pokja PLN (2019) shows that the relaxation of this registration regulation increased the number of overseas voters, which consisted of 9,727 traveled voters (DPTb) and 325,952 new voters (DPK) (Kelompok Kerja Pembina Pemilihan Umum Luar Negeri, 2019).

Thus, this study attempts to fill in the gap by examining the implementation of external voting in developing countries. Particular attention is given to the operations of overseas polling stations by conducting a case study of the 2019 election held by the Indonesian government and observing the real implementation of external voting and voter participation through a survey at the Tokyo polling station. 


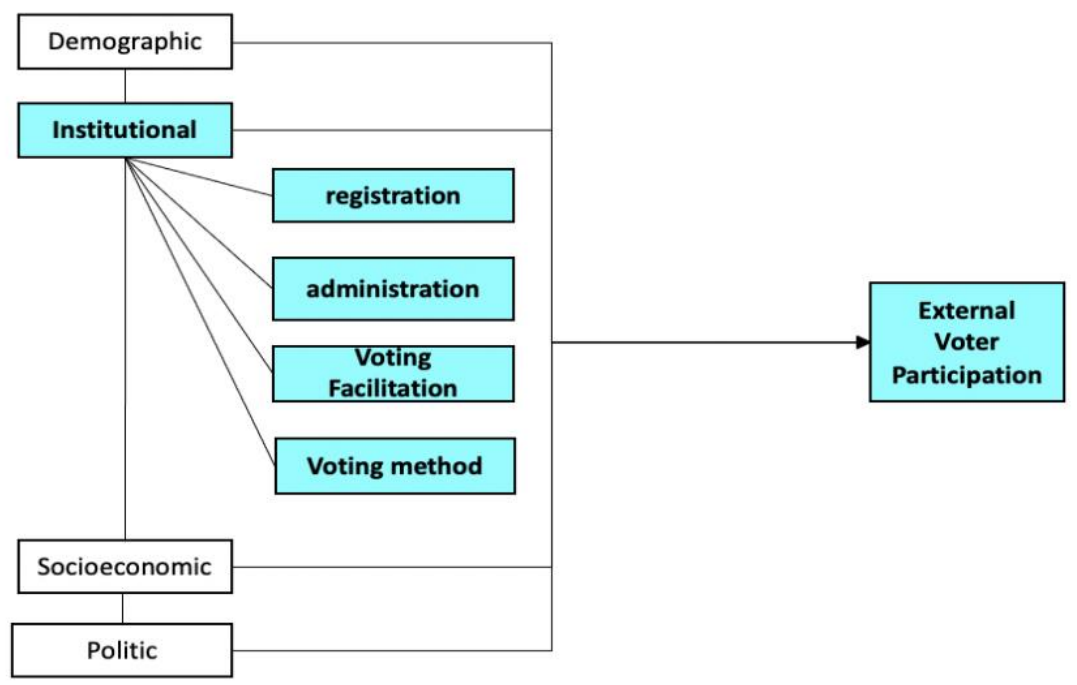

Figure 1. Institutional Factors diagram for External Voter Participation

The influential factors on voters' participation can be seen in Figure 1. This study will focus on institutional factors, significant factors of voter participation. Registration, which is one of the institutional factors affecting voter participation (Lafleur \& Chelius, 2011), will be used in this study. Registration is the initial part of the voting process, which determines the number of registered voters who can exercise their voting rights. The second institutional factor to be used is voting administration, where the implementation of voting abroad is complex (Ellis et al., 2007; Hafizy, 2017). Furthermore, voting facilitation, which is an important factor in voting (Bauböck, 2007) will be an important object of the study considering that Indonesia has provided a polling station and voting committee in 130 embassies or consulates. Finally, the voting method would also affect the level of voter participation, as suggested by Belchior et al., (2018).

\section{Methodology}

This study employed qualitative approaches to examine the research questions using both primary and secondary data. Primary data was collected through an online survey given to Indonesian citizens living in the Kanto and nearby areas. A simple online questionnaire using Google forms was distributed to respondents. It was sent through email and social media, Instagram, and WhatsApp, starting from June 18,2020, and ending on June 30, 2020. The online questionnaire was sent to 299 email addresses of Indonesian residents in Chiba, Saitama, Kanagawa, and Tokyo and several Instagram and WhatsApp accounts. The questionnaire consisted of 18 questions, 15 close-ended and three open-ended. See Appendix for the list of questions.

A total of 65 respondents, 28 men, and 37 women have a higher education. The focus of research on respondents with higher education is based on the rapid development of higher education in Indonesia (Pratomo et al., 2020). According to law No. 12 of 2012, "higher education is the education level after secondary education including diploma, undergraduate, master, doctoral, professional, and specialist programs, which are organized by universities based on Indonesian culture." The participants were selected to observe the behavior of white-collar citizens toward Indonesia's election.

Secondary data was primarily obtained from Advisory Working Groups for Overseas Elections (Kelompok Kerja Pembina Pemilihan Umum Luar Negeri, 2019), Overseas Election Committee (PPLN), National Election Commission (KPU), and Ministry of Foreign Affairs. Officials from each of the institutions as mentioned above were contacted to obtain access to records and documents on external voting and overseas citizens.

Descriptive analysis was utilized to provide an overview of the 2019 external voting implementation using quantitative data (at the aggregate level unit analysis per polling station) and relevant sources such as academic papers, government reports, and publications. In the qualitative approach, an online survey was administered to Indonesian citizens living in the Kanto and nearby areas, Japan, related to their experiences, perceptions, and participation in the 2019 election. 
The first part of the analysis in this paper explores the implementation of external voting by the Indonesian government and overseas voters. This analysis uses relevant sources such as academic papers, government reports or publications, and macro data (per polling stations unit analysis) related to the 2019 external voting from Pokja PLN and National Election Commission. The second part of the analysis explores the findings from the survey given to Indonesian citizens living in the Kanto and nearby areas. The survey results present the real condition of external voting at the micro-level. The analysis of this paper focuses on institutional factors such as registration, administration, voting facilitation, voting methods, and how respondents' experiences of institutional factors influence their political behavior.

\section{Results and Discussion}

\subsection{The 2019 External Voting}

The 2019 election was the 12th general election carried out by the Indonesian government. Therefore, to improve the quality of election execution, the government introduced many policy changes. Some policy changes were related to the administration of elections, for example, the simultaneous election of presidential and parliamentary elections, the reduction of the number of voters per polling station from 500 to 300 voters per polling station, thereby increasing the number of polling stations by almost 50\% from the previous election in 2014 (Badan Pusat Statistik, 2019, p. 25), and adjusting the number of Overseas Election Committee members based on the number of voters (Election Commission Regulation Number 4, 2018).

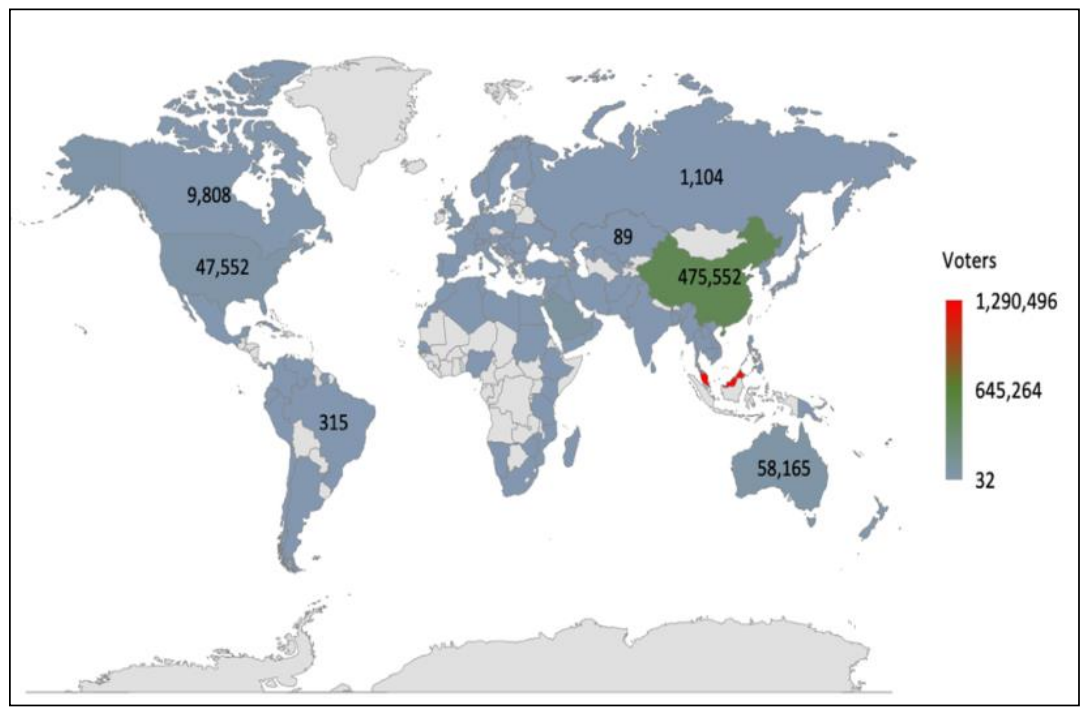

Figure 2. Overseas Voters Distribution (Compiled by the author based on data from the National Election Commission)

As Indonesia started the external voting in the second election, the 2019 election was the 11th external voting. Data from Kelompok Kerja Pembina Pemilihan Umum Luar Negeri (Kelompok Kerja Pembina Pemilihan Umum Luar Negeri, 2019) revealed that the total number of registered overseas voters in DPT (Permanent Voter List) in this period was 1,991,145 voters covering 96 countries with the highest number of voters from Malaysia, followed by China and Singapore. This number was only about $1 \%$ of the total number of voters, which reached 192,770,661 voters spread across 34 provinces and overseas. However, the number of overseas voters exceeded the number of voters in some provinces in Indonesia (Badan Pusat Statistik, 2019). This is most likely due to the unequal distribution of the population in Indonesia and a large number of Indonesian citizens abroad. Voters distribution map can be seen in Figure 2.

The comparison of the number of overseas voters and the number of Indonesian citizens abroad based on relevant sources shows a significant difference. Even though each of the relevant sources presents a different number of Indonesian emigrants, these figures are still far more than the number of overseas voters in the 2019 elections. For instance, Muhidin \& Utomo (2016) revealed that data from 4 different sources showed a significant difference in the number of Indonesian citizens abroad in 2013. This number ranges from 2.9 million - 6 million citizens. Meanwhile, the latest migrant data from the UN 
Migrant Stock, the most widely used data source, shows that the number of Indonesian citizens abroad in 2019 was 4,532,992 people. Data on the age of all emigrants in each country from the UN Migrant Stock were used to obtain the number of voting age populations of emigrants. It was found that the proxy for Indonesian emigrants aged 17 and over was 3,868,213, a figure that is almost double the number of overseas voters in the 2019 DPT.

Indonesia has a long experience in implementing external voting. Provisions on political rights for Indonesian citizens abroad began to be regulated in 1953 through election law number 7 of 1953 (Ellis et al., 2007). However, its implementation was only carried out in 1971 (second general election) during the new order period (Pamungkas et al., 2019). In the election, overseas voters were allowed to vote for parliamentary members in the House of Representative (DPR) during the 1971-2019 elections and Presidential candidates during the 2004-2019 elections. However, from the first election in 1955 until the 2019 election, there has been no direct representation of overseas voters in the parliament. The overseas voters vote for Jakarta's two constituencies, which consist of South Jakarta, Central Jakarta, and overseas. In its implementation, the government consistently forms Overseas Election Committee (PPLN) and prepares polling stations at the Indonesian embassies and consulate offices.

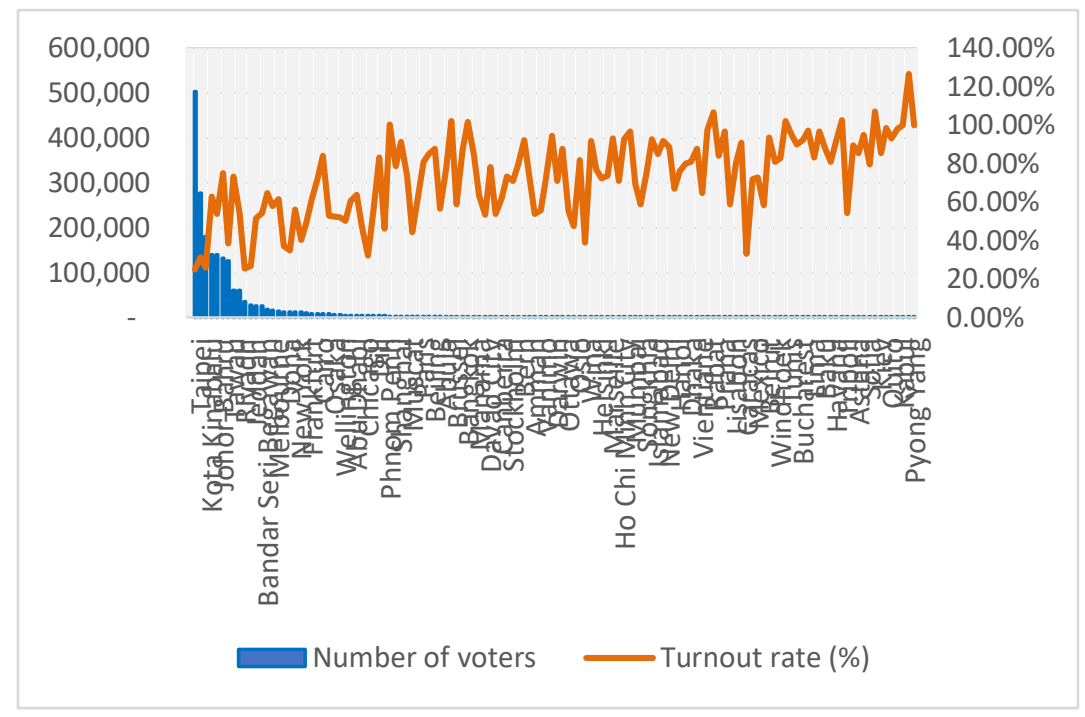

Figure 3. Overseas Voters and Turnout Rates by Polling Stations (Compiled by the author based on data from the National Election Commission)

Overseas citizen participation in the 2019 election is lower than domestic citizens. Of the $1,991,145$ overseas voters registered in the list of permanent voters (DPT), 847,037 voters successfully cast their ballot resulting in a $42.54 \%$ participation rate for the presidential election (Kelompok Kerja Pembina Pemilihan Umum Luar Negeri, 2019). This rate is about half of the participation rate in the home country, which reached $82.38 \%$ and the lowest compared to the participation rate in each of the 34 provinces in Indonesia (Badan Pusat Statistik, 2019). Overseas voter participation also varied at each polling station; data from Pokja PLN shows that the participation ranges between $24.92 \%-126.67 \%$. The participation rate that exceeded $100 \%$ was due to additional voters other than the permanent voters on DPT who cast a ballot, namely traveled voters on DPTb and new voters on DPK. The turnout variation can be seen in Figure 3.

Election Commission Regulation Number 12 (2018) categorized three types of overseas voter lists based on their registration:

- DPT LN (Daftar Pemilih Tetap Luar Negeri - List of permanent overseas voters) consists of the overseas voter list from the previous election and overseas citizens listed in the consular database at the Indonesian Embassy/Consulate, which the committees used to synchronize, compile and update the permanent voter list.

- DPTb LN (Daftar Pemilih Tetap Tambahan Luar Negeri - List of additional permanent overseas voters) consists of voters who have listed in the DPT of a polling station who, because of a certain condition, such as residence change due to assignment or relocation, cannot use their voting rights 
at the polling station where they are registered. These voters can request a move to vote at the nearest polling station.

- DPK LN (Daftar Pemilih Khusus Luar Negeri - List of specific overseas voters) consists of voters who have not registered in the permanent voter list (DPT) but then register themselves to vote using passports or other travel documents proving that they are living abroad.

Voters on the list of permanent overseas voters (DPT LN) can be assumed as automatically registered voters because they are automatically listed as voters on the DPT LN. On the other hand, voters on the list of additional permanent overseas voters (DPTb LN) and the list of specific overseas voters (DPK LN) can be assumed as self-registered voters because they need to register themselves to vote.

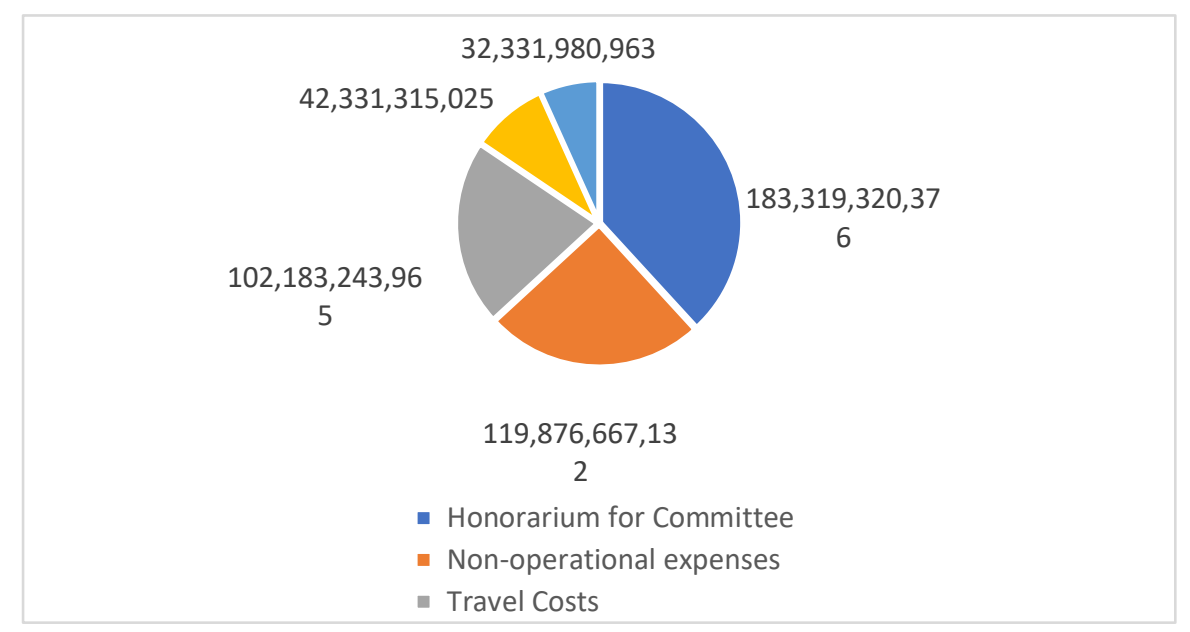

Figure 4. Total Expenses at 130 Polling Stations (Compiled by the author based on data from the National Election Commission)

The implementation of overseas voting involves the government's significant role. One of them is related to budget allocation. In the 2019 external voting, the government allocated a sizable budget to 130 polling stations which reached more than 621 billion rupiahs (equal to US\$ 41 million) (Kelompok Kerja Pembina Pemilihan Umum Luar Negeri, 2019). This fund was used to support various activities at the overseas polling station, which included the committee's honorarium (38.19\%), expense related to information dissemination about elections and meetings, non-operational expenses (24.97\%), travel cost (21.29\%), logistics expenditure (8.82\%), and rental expenditure 6.74\%). Of the total allocated funds, around $77 \%$ was spent on 130 overseas polling stations for the 2019 external voting. The proportion of the expenses can be seen in Figure 4.

Additionally, the government formed four ad hoc committees consisting of the Overseas Election Committee (PPLN), Overseas Voting Organizing Group (KPPSLN), Voter Data Updating Committee (Pantarlih), and Overseas Election Supervisory Committee (Panwaslu).

There were three methods of voting for overseas voters. Unlike domestic voters, overseas voters can use one of the three voting methods provided. First is direct voting at polling stations; the second is absentee voting through the postal service for voters who cannot go to the polling stations; and the last is voting through a ballot box which is provided for a group of voters who gather, work, or live in one area. In the 2019 elections, the government provided 789 polling stations, 2,354 ballot boxes, and 438 postal service units to 130 locations in 96 countries (Kelompok Kerja Pembina Pemilihan Umum Luar Negeri, 2019).

The implementation of democracy in Indonesia has experienced significant improvement since the first elections in 1955. This shows the government's commitment to implement democracy in Indonesia which is apparent from the implementation of external voting from the second election in 1971 to the current election in 2019. The government consistently supports the implementation of voting abroad, such as regulations, funds, and human resources. 


\subsection{Highly Educated Voters in Tokyo Polling Station}

In addition to the Osaka polling station, the Tokyo polling station is one of the two polling stations in Japan provided by the government for the 2019 external poll. Each polling station serves voters who live close to the polling station. The Tokyo polling station serves Indonesians living in 30 prefectures close to Tokyo, such as Hokkaido, Aomori, Iwate, Akita, Miyagi, Yamagata, Fukushima, Gunma, Ibaraki, Tochigi, Saitama, Chiba, Tokyo, Kanagawa, Niigata, Toyama, Ishikawa, Nagano, Gifu, Yamanashi, Shizuoka, Aichi, Fukuoka, Saga, Nagasaki, Oita, Kumamoto, Miyazaki, Kagoshima, and Okinawa (PPLN Tokyo, 2019a). The Tokyo polling station is located at Balai Indonesia, the Republic of Indonesia School at 4 Chome-6-6 Meguro, Meguro City, Tokyo 153-0063, two kilometers from the Indonesian Embassy.

Three online accounts were used to disseminate information about overseas voting in Tokyo. The first is the Tokyo PPLN Facebook account with 5,864 followers. This media is quite active and comprehensive in conveying information about voting in Tokyo. The second is the https://ppln2019.tokyo page which is linked to the Tokyo PPLN Facebook account, but at the time of this study, the page was no longer accessible. The last is the official website of the Indonesian Embassy in Tokyo https://kbritokyo.jp. As this page is not specifically made for the election, it does not contain much information about voting in Tokyo.

The government provided some assistance for the 2019 external voting in Tokyo. These supports include fund allocation of around IDR 4 billion (equivalent to the US $\$ 300,000$ ), ad hoc committee formation, consisting of 10 Overseas Election Committee (PPLN) and 31 overseas voting organizer group (KPPSLN), 7 for voting at the polling station and 24 for voting by post, and 130 overseas polling stations (Kelompok Kerja Pembina Pemilihan Umum Luar Negeri, (Kelompok Kerja Pembina Pemilihan Umum Luar Negeri, 2019).

Two voting methods were used to serve 16,799 registered voters on the permanent voter list (DPT). The first was direct voting at the polling station, which was allocated for 1,182 voters (only $7.04 \%$ ). The second was absentee voting by post, which was allocated for the majority of the voters $(92.96 \%)$ 15,617 voters. The voting by ballot box method was not provided at the Tokyo polling station. There was a total of eight postal service groups provided to serve voting by post. However, only five voting booths were provided at the polling station (Oktaviane, 2019) to serve direct voting at the polling station.

However, the actual number of voters who came to the polling station doubled the DPT voters registered to vote at the polling station. Data from the Advisory Working Groups for Overseas Elections in (2019) recorded that there were 1,293 additional voters. About 657 voters were transferred from other polling stations, w categorized as additional voters on DPTb, and 636 were new voters who registered on the voting day, categorized as specific voters on DPK. This considerable increase in the number of voters who came on voting day, which was not anticipated, caused overcrowding of queueing voters and overload work for the committee.

Indonesian citizen participation in the 2019 External voting in Tokyo was below the average participation rate of the 130 overseas polling stations. The 2019 external voting at the Tokyo polling station on Sunday, April 14, 2019, from 08:00 to 22:42 recorded 1,937 voters out of 2,222 voters (Indonesian Embassy in Tokyo, 2019). However, the total participation rate according to data from Kelompok Kerja Pembina Pemilihan Umum Luar Negeri (Kelompok Kerja Pembina Pemilihan Umum Luar Negeri, 2019) was only $57.82 \%$. It implies that from the 16,799 registered voters on the permanent voter list (DPT), only 9,713 voters successfully cast ballots. This participation rate was below the average participation rate of 130 overseas polling stations, which was $72.84 \%$. The voting resulted in Joko WidodoMar'ruf Amin victory by $61.31 \%$ votes over Prabowo Subianto-Sandiaga Uno who collected $36.38 \%$ votes.

\subsection{Discriminative Analysis of Respondents}

Respondents of the survey come from six prefectures in the Kanto area: Tokyo, Saitama, Kanagawa, Chiba, Shizouka, and Ibaraki. These prefectures are closer to Tokyo polling stations than the Osaka polling station. They consist of almost an equal number of men and women, with $43 \%$ male respondents and $57 \%$ female and the average age being 29 years old. About $51 \%$ of respondents had an age range of $21-30$ years, and $37 \%$ of respondents had an age range of $31-40$ years. The discriminative data of respondents can be seen in Table 1. 
Table 1: Discriminative list of respondents

\begin{tabular}{|c|c|c|c|c|c|c|c|c|c|c|c|c|c|c|c|}
\hline \multirow[t]{2}{*}{ Characteristics } & \multicolumn{3}{|c|}{$17-20$} & \multicolumn{3}{|c|}{$21-30$} & \multicolumn{3}{|c|}{$31-40$} & \multicolumn{3}{|c|}{$41-50$} & \multicolumn{2}{|c|}{$51-60$} & \multirow{2}{*}{$\begin{array}{l}\text { Grand } \\
\text { Total }\end{array}$} \\
\hline & $\mathbf{F}$ & $M$ & Tot & $\mathbf{F}$ & $M$ & Total & $\mathbf{F}$ & $\mathbf{M}$ & Total & $\mathbf{F}$ & $M$ & Total & $\mathbf{M}$ & Total & \\
\hline \multicolumn{16}{|l|}{ Occupation } \\
\hline Student & 2 & & 2 & 11 & 10 & 21 & 4 & 3 & 7 & & 1 & 1 & & - & 31 \\
\hline Govt. Official & & & - & 2 & 1 & 3 & 6 & 3 & 9 & & & - & & - & 12 \\
\hline Specialist & & & - & 1 & 2 & 3 & 3 & & 3 & & & - & 1 & 1 & 7 \\
\hline Private & & 1 & 1 & 3 & 3 & 6 & 2 & 1 & 3 & 1 & 2 & 3 & & - & 13 \\
\hline \multirow[t]{2}{*}{ Housewife } & & & - & & & - & 2 & & 2 & & & - & & - & 2 \\
\hline & 2 & 1 & 3 & 17 & 16 & 33 & 17 & 7 & 24 & 1 & 3 & 4 & 1 & 1 & 65 \\
\hline \multicolumn{16}{|l|}{ Education } \\
\hline $\begin{array}{l}\text { Undergraduate/ } \\
\text { Graduate }\end{array}$ & 2 & 1 & 3 & 16 & 14 & 30 & 16 & 6 & 22 & 1 & 2 & 3 & 1 & 1 & 59 \\
\hline \multirow[t]{2}{*}{ Doctoral } & & & - & 1 & 2 & 3 & 1 & 1 & 2 & & 1 & 1 & & - & 6 \\
\hline & 2 & 1 & 3 & 17 & 16 & 33 & 17 & 7 & 24 & 1 & 3 & 4 & 1 & 1 & 65 \\
\hline \multicolumn{16}{|l|}{ Length of stay } \\
\hline$>0-3$ years & 2 & 1 & 3 & 9 & 12 & 21 & 11 & 5 & 6 & & 2 & 2 & 1 & 1 & 43 \\
\hline$>3-5$ years & & & - & 4 & 4 & 8 & & & - & & 1 & 1 & & - & 9 \\
\hline$>5-9$ years & & & - & 2 & & 2 & 3 & 2 & 5 & & & - & & - & 7 \\
\hline \multirow[t]{2}{*}{$>9$ years } & & & - & 2 & & 2 & 3 & & 3 & 1 & & 1 & & - & 6 \\
\hline & 2 & 1 & 3 & 17 & 16 & 33 & 17 & 7 & 24 & 1 & 3 & 4 & 1 & 1 & 65 \\
\hline
\end{tabular}

The respondents were highly educated citizens, most of whom had a bachelor's or master's degree, and about $9 \%$ had a doctorate degree. The respondents' occupation was mostly students (48\%) followed by professionals in the private sector (20\%), government employees (18\%), specialists (11\%), and housewives (3\%). It is assumed that students tend to check their emails more often than other professions to give the most responses. More than half of the respondents were short-term residents in Japan, while about $66 \%$ of respondents had stayed in Japan between $>0-3$ years. This is consistent with the students' durational stay with a study period of $1-3$ years

\subsection{Registration Condition}

According to the survey, the majority of respondents were self-registered voters. About $75 \%$ of respondents registered themselves as voters, while the remaining $22 \%$ stated they were automatically registered. Most respondents who registered themselves claimed to have lived in Japan for up to three years were aged 21-30 years old and were female. On the other hand, the automatically registered respondents had a long span of stay in Japan that was spread evenly between $>0-3$ years old to $>9$ years old; most were aged 31-40 years old and were female.

Nevertheless, among the self-registered respondents, six respondents stated that the existing registration procedure was complex or very difficult. These are self-registered voters who had lived in Japan for a short period and up to three years. Even though they are all university graduates, a short stay might contribute to the difficulties encountered in registration. The voters must register themselves due to the absence of relevant data in the election committee database. They also faced difficulty registering due to a lack of information about the election.

\subsection{Four Types of Problems in the Voting Process}

The results of the questionnaire showed that 25 respondents (about 38\%) encountered problems/difficulties regarding the voting process. These respondents reported 39 problems in polling facilitation (13 complaints) followed by registration (10 complaints), voting method ( 8 complaints), and administration (8 complaints) used in the 2019 external voting. 




Figure 5: Type of problems faced by respondents

Problems reported by respondents can be categorized into four categories. Ordered in sequence from the most frequently complained, the four problems are as follows: 1) Time consumed in the voting process (15 complaints); 2) Poor organizational management (9 complaints), 3) Lack of information about elections (7 complaints), and 4) Citizens who were not automatically registered as voters (5 complaints). The number of complaints about each category can be seen in Figure 5.

\section{a) Time-consuming voting process}

The length of time required in the voting process is the most complained problem. Approximately $38 \%$ of such complaints, or 15 cases, were reported in the survey. 13 voters reported this time concern on three aspects: administration, facilitation of voting, and the voting method. However, two more voters stated that they faced this problem in two aspects simultaneously: administration and voting facilitation, resulting in 15 time-related problems. The respondents stated that they had to wait in a long queue to vote and the election was poorly organized, causing overcrowding and confusion.

The time-related complaints were expressed by voters with a duration of stay in Japan of up to 3 years and had registered themselves as voters with the committee. It implies that these respondents are most likely not included in the overseas permanent voter list (DPT LN). They are included as additional voters who had moved to vote from another polling station (DPTb LN) or new voters who had registered themselves with the committee (DPK LN). Two of the 12 respondents who complained about the voting time were confirmed as voters in the DPTb ( 1 respondent) and voters in the DPK (1 respondent). This is similar to Oktaviane's (Oktaviane, 2019) study, which found hundreds of DPK voters had to queue for hours to cast their ballots for the 2019 vote in Tokyo.

Voters included on specific lists of overseas voters (DPK) at the Tokyo polling station must follow a number of procedures that require extra time to vote. (PPLN Tokyo, 2019b) revealed that these voters must follow three steps. First, they had to register with the committee, which could only be done since the polling station started operating at 09:00. Second, after registration, they were required to take a queue number between 16:00 and 18:00. Third, they started casting ballots at 17:00 based on the queue numbers and the availability of ballot papers. These new voters were only allowed to vote one hour before the voting ended or had to wait for voters on the permanent voter list (DPT) and additional list (DPTb) to finish their casting ballots. A large number of new voters on specific voter lists (DPK) extended the queue of voters and the length of time for voting. 


\section{b) Poor organization and management}

The second most frequent problem faced by respondents was the poor management of the voting organization. A total of eight respondents raised nine problems related to the management of the voting organization. This complaint was conveyed not only by six respondents of the self-registered voters (DPK and DPTb) but also by two respondents of the automatically registered voters (DPT). Four respondents in voting facilitation reported this problem.

Of the nine issues related to organizational management, three respondents mentioned the lack of committee members on duty compared to the large number of voters who came to the polling station. This condition is in line with data from Kelompok Kerja Pembina Pemilihan Umum Luar Negeri (Kelompok Kerja Pembina Pemilihan Umum Luar Negeri, 2019), that the number of committee personnel assigned to organize voting at the polling station was only seven persons. This number was inadequate compared to the number of voters who came to the polling station, which reached more than 2,000 (Indonesian Embassy in Tokyo, 2019).

Another problem raised was the lack of polling booths provided for voters. Two respondents reported this problem. The committee only provided five voting booths in the 2019 election at the Tokyo polling station (Oktaviane, 2019). This figure was only half those provided in the previous election in 2014 (Indonesian Embassy in Tokyo, 2014). For comparison, the 2014 voting only served 9,092 DPT voters, only about half of the registered voters in the 2019 DPT with 16,799 voters.

The number of voting booths provided was insufficient compared to the number of voters. According to the government regulations on Election Commission Regulation Number 4/2018, each polling station serves a maximum of 300 voters. While in the 2019 external voting in Tokyo, one polling station with only five polling booths served more than 2,000 voters. This condition caused long queues of voters at polling stations and potentially resulted in many voters unable to cast their votes.

\section{c) Lack of information about voting}

The third problem raised by respondents was the lack of information received about voting. Six respondents reported a total of seven complaints with almost all problems concerning registration. Similar to the complaints about the time consumed, this complaint was also delivered by self-registered voters with a stay in Japan of up to 3 years. Surprisingly, one respondent with a stay of 5 to 9 years also submitted the same complaint.

The results from the questionnaire showed that the limited media used to broadcast the information and the less informative content caused the lack of information received about voting. For example, one respondent revealed that information about voting was less spread on other channels and media outside the Indonesian Embassy website. On the other hand, other respondents stated that information on the website of the Indonesian Embassy was unclear. Furthermore, other respondents more specifically stated that the registration period was not well informed.

\section{d) Not automatically registered as a voter}

The fourth problem addressed by the respondents is that the respondents were not automatically registered as voters. This was reported in five cases by five respondents who were selfregistered voters with the length of stay in Japan of up to three years.

The survey results indicate that the database of Indonesian citizens at the Indonesian Embassy was not used properly by the committee to update the voter data. This caused Indonesian citizens who had reported themselves to the Indonesian Embassy to be excluded as automatically registered voters on the DPT so that they had to register themselves to vote. This was confirmed by one respondent who had reported himself to the Indonesian Embassy long in advance, but his data was not included on the voter list (DPT).

\section{e) Other problems}

Finally, two other problems were reported by two respondents, indicating their pessimistic attitude toward the existing voting system. The response suggested the importance of overseas citizen data integration in compiling voter lists to cover all overseas citizens. Another response highlighted the possibility of using an online voting system to overcome the problems at polling stations. 


\subsection{Respondents Who Did Not Vote}

Out of 65 respondents, nine respondents did not use their voting rights. Almost half of them, four respondents, revealed that the reason for not voting was that they encountered problems/difficulties in the voting process, while other (five respondents) stated that they were busy working. These four respondents mostly complained about the length of time needed in the voting process due to long and irregular queues, poor organizational management, and the lack of personnel on duty and polling booths compared to the number of voters. The lack of information received related to voting was mentioned less frequently.

\section{Conclusion}

The Indonesian external voting has gone through a long history and has been in line with the country's democracy. The government has consistently provided substantial support when conducting voting from outside its territory. Significant funds and human resources were allocated to hold external voting. However, a lack of facilities for 2019 external voting was still observed. The number of voting booths and committee personnel failed to accommodate the excess voters at the Tokyo polling station.

Even though highly educated respondents tended to have a high awareness of home country elections, they are prone to fail in casting their ballots due to the length of time needed, poor organizational management of the voting, and lack of information received about voting. On the other hand, the survey results reveal that registration restrictions did discourage their participation, which is evident from the significant enthusiasm of respondents to register themselves as voters.

It is suggested that the committee consider expanding the channels and media used to disseminate information about elections so that overseas citizens can obtain sufficient information to avoid problems in the voting process. They may also assess the possibility of using more effective voting methods such as online voting.

\section{Acknowledgments}

I would like to thank the University of Indonesia, the National Graduate Institute for Policy Studies Japan, Bappenas, the Ministry of Foreign Affairs, Kelompok Kerja Pembina Pemilihan Umum Luar Negeri, my family and colleagues for the opportunity, guidance, and support during the writing of this research paper.

\section{References}

Alarcon Jr, J. (2012). Diaspora and Democracy: Overseas Absentee Voting, Elections, and the Challenges for a Working Democracy in the Philippines. 立命館言語文化研究, 13(3), 183-200.

Badan Pusat Statistik. (2019). Statistik Politik 2019.

Battiston, S., \& Mascitelli, B. (2008). The challenges to democracy and citizenship surrounding the vote to Italians overseas. Modern Italy, 13(3), 261-280. https://doi.org/10.1080/13532940802069572

Bauböck, R. (2007). Stakeholder citizenship and transnational political participation: A normative evaluation of external voting. Fordham L. Rev., 75, 2393.

Belchior, A. M., Azevedo, J., Lisi, M., \& Abrantes, M. (2018). Contextual reasons for emigrants' electoral participation in home country elections: The Portuguese case. Journal of Contemporary European Studies, 26(2), 197-214. https://doi.org/10.1080/14782804.2017.1413641

Blais, A., Daoust, J. F., Dassonneville, R., \& Péloquin-Skulski, G. (2019). What is the cost of voting? Electoral Studies, 59(February), 145-157. https://doi.org/10.1016/j.electstud.2019.02.011

Burgess, K., \& Tyburski, M. D. (2020). When parties go abroad: Explaining patterns of extraterritorial voting. Electoral Studies, 66(May). https://doi.org/10.1016/j.electstud.2020.102169

Cain, B. E., Mac Donald, K., \& Murakami, M. H. (2008). Administering the overseas vote. Public Administration Review, 68(5), 802-813. https://doi.org/10.1111/j.1540-6210.2008.00921.x

Ciornei, I., \& Østergaard-Nielsen, E. (2020). Transnational turnout. Determinants of emigrant voting in home country elections. Political Geography, 78(December 2018). https://doi.org/10.1016/j.polgeo.2020.102145

Collyer, M. (2014). A geography of extra-territorial citizenship: Explanations of external voting $t$. Migration Studies, 2(1), 55-72. https://doi.org/10.1093/migration/mns008

Department of Economic and Social Affairs United Nations. (2020). International migrant stock 2019. Un.Org.https://www.un.org/en/development/desa/population/migration/data/estimates2/esti mates19.asp 
Ellis, A., Navarro, C., Moralles, I., \& Wall, A. (2007). Voting From Abroad Database. International Idea.

Hafizy, W. (2017). Penjaminan Hak Pilih Warga Negara di Luar Negeri: Kajian Instrumentasi Pemilu. In Gadjah Mada University. Gadjah Mada University.

Hanmer, M., Herrnson, P. S., \& Smith, C. (2015). The Impact of E-mail on the Use of New Convenience Voting Methods and Turnout by Overseas Voters: A Field Experiment to Address Their Challenges with New Technology. Election Law Journal: Rules, Politics, and Policy, 14(2), 97-110. https://doi.org/10.1089/elj.2014.0266

Herrnson, P. S., Koh, H. Y., Hanmer, M. J., \& Smith, C. (2015). Message, milieu, technology, and turnout among military and overseas voters. Electoral Studies, 39, 142-152. https://doi.org/10.1016/j.electstud.2015.04.002

Indonesian Embassy in Tokyo, I. and S. C. F. (2014). Gerimis dan Dingin Bukan Hambatan Bagi WNI di Tokyo. Kbritokyo.Jp. https://kbritokyo.jp/2014/12/gerimis-dan-dingin-bukan-hambatan-bagiwni-di-tokyo-untuk-datangi-tps/

Indonesian Embassy in Tokyo, I. and S. C. F. (2019). Pelaksanaan Pemilu 2019 di Tokyo. Kbritokyo.Jp. https://kbritokyo.jp/2019/04/pelaksanaan-pemilu-2019-di-tokyo/

Kaario, M. I. (2018). Communicating Overseas Absentee Voting ( OAV ) to Filipinos in Finland: A transnational communication perspective. Haagia-Helia University of Applied Sciences.

Kelompok Kerja Pembina Pemilihan Umum Luar Negeri. (2019). Laporan Kelompok Kerja Pembina Pemilihan Umum Luar Negeri Tahun 2019.

Lafleur, J. M., \& Chelius, L. C. (2011). Assessing Emigrant Participation in Home Country Elections: The Case of Mexico's 2006 Presidential Election. International Migration, 49(3), 99-124. https://doi.org/10.1111/j.1468-2435.2010.00682.x

Low, C. C. (2018). MyOverseasVote: Liberalism and extraterritorial citizenship. Citizenship Studies, 22(7), 745-768. https://doi.org/10.1080/13621025.2018.1508416

Muhidin, S., \& Utomo, A. (2016). Global Indonesian Diaspora: How many are there and where are they? JAS (Journal of ASEAN Studies), 3(2), 93. https://doi.org/10.21512/jas.v3i2.847

Murray, J. (2012). Absent voting, the Help America Vote Act 2002, and the American overseas voter: An analysis of policy effectiveness and political participation. In Newcastle University (Issue November).

Oktaviane, D. (2019). Pemilu 2019, WNI di Tokyo Rela Antre Berjam-jam. Tempo.Co.Id. https://video.tempo.co/read/14282/pemilu-2019-wni-di-tokyo-rela-antre-berjam-jam

Pamungkas, M., Cholik, A., Sari, D. M., Yusnita, E., Rahman, H. A., Situmorang, N., Sunjaya, S., Fatimah, S., Suharti, \& Sugiyanto, W. (2019). Jejak Demokrasi Pemilu 1955. In Arsip Nasional Republik Indonesia.

PPLN Tokyo. (2019a). Our Story. Facebook.Com. https://www.facebook.com/Pemilu2019Jepang/

PPLN Tokyo. (2019b). TOLONG DI BACA DENGAN SEKSAMA. Facebook.Com. https://www.facebook.com/Pemilu2019Jepang/

Pratomo, D. S., Syafitri, W., \& Anindya, C. S. (2020). Expanding Middle Class in Indonesia. The Journal of Indonesia Sustainable Development Planning, 1(3), 307-312. https://doi.org/10.46456/jisdep.v1i3.103.

Şahin-Mencütek, Z., \& Erdoğan, M. M. (2016). The Implementation of Voting from Abroad: Evidence from the 2014 Turkish Presidential Election. International Migration, 54(3), 173-186. https://doi.org/10.1111/imig.12229

Sevi, S., Mekik, C. S., Blais, A., \& Çakır, S. (2020). How do Turks abroad vote? Turkish Studies, 21(2), 208230. https://doi.org/10.1080/14683849.2019.1607311

Smith, C. (2010). These are our Numbers: Civilian Americans Overseas and Voter Turnout. OVF Research Newsletter, 2(4), 1-13. 